\title{
Semiotika Tanda Verbal dan Tanda Visual Iklan Layanan Masyarakat
}

\author{
Sumbo Tinarbuko \\ Fakultas Seni Rupa dan Program Pascasarjana ISI Yogyakarta. \\ Jalan Parangtritis KM. 6, Sewon Bantul, Yogyakarta
}

\begin{abstract}
This article uses qualitative research method by describing, interpretating, and explaining the connotation meaning of public service advertisingLater on it is classified based on the sociolinguistics, pragmatics, visual communication design, and semiotics theory.

The method of semiotics visual communication analysis is also used as an analysis method for verbal and visual data. It is used as one of public service advertising reading methods do to the tendency to see things, such as art, culture, social, visual communication design, and public service advertising as the phenomenon of language and sign.

It is important to understand the semiotics of visual communication theory, because it can be used to enlarging the imagination, insight, and knowledge about the importance of understanding semiotics of visual communication, both on the creation and designing public service advertising process or process of reviewing the public service advertising object. Practically, it gives a positive adventage for the advertising practitioners or students at the Department of Advertising and Visual Communication Design.
\end{abstract}

Keywords: sign, code and meaning of public service advertising, semiotics of visual communication, verbal message and visual message

\begin{abstract}
ABSTRAK
Tulisan ini menggunakan metode penelitian kualitatif dengan cara mendeskripsikan, menginterpretasikan, dan menerangkan makna konotasi iklan layanan masyarakat yang kemudian diklasifikasikan berdasarkan pada bangunan teori sosiolinguistik, teori pragmatik, teori desain komunikasi visual, dan teori semiotika.

Metode analisis semiotika komunikasi visual juga dimanfaatkan sebagai metode analisis data verbal dan data visual, sebagai salah satu metode pembacaan Iklan Layanan Masyarakat (ILM) akibat adanya kecenderungan untuk memandang berbagai hal, seperti seni, budaya, sosial, desain komunikasi visual, dan ILM sebagai fenomena bahasa dan tanda.

Penguasaan teori semiotika komunikasi visual ini penting karena dapat digunakan sebagai bahan referensi verbal dan visual bagi khalayak untuk memperluas imajinasi, wawasan, dan pengetahuan mengenai pentingnya memahami semiotika komunikasi visual baik dalam proses penciptaan dan perancangan iklan layanan masyarakat maupun proses mengkaji objek iklan layanan masyarakat. Secara praktikal memberikan manfaat yang positif bagi praktisi periklanan dan biro iklan pada umumnya maupun civitas akademika Jurusan Periklanan dan Desain Komunikasi Visual pada khususnya.
\end{abstract}

Kata kunci: tanda, kode dan makna iklan layanan masyarakat, semiotika komunikasi visual, pesan verbal dan pesan visual 


\section{PENDAHULUAN}

Periklanan, selain merupakan kegiatan pemasaran, juga merupakan aktivitas komunikasi. Kegiatan pemasaran meliputi strategi pemasaran, yakni logika pemasaran yang dipakai unit bisnis untuk mencapai tujuan pemasaran (Kotler, 1991: 416). Menurut Liliweri (1991: 20), aktivitas komunikasi adalah penciptaan interaksi perorangan dengan menggunakan tanda yang tegas. Komunikasi juga berarti pembagian unsur-unsur perilaku, atau cara hidup dengan eksistensi seperangkat ketentuan dan pemakaian tanda-tanda yang telah disepakati.

Atas nama target waktu, menurut pakar periklanan internasional David Ogilvy seperti tertulis dalam bukunya berjudul: Ogilvy on Advertising, seperti dikutip Sumbo Tinarbuko (2009: 11), iklan merupakan medium informasi yang mengandung bobot seni. Karena itulah rancangan iklan selalu menggunakan teknik tertentu untuk mencapai tujuannya, di antaranya, pertama, penjualan ide yang menjadi andalan terkait masa berlakunya suatu barang atau jasa untuk jangka waktu panjang. Kedua, penyebaran ide perihal keuntungan pihak komunikan bila menerima ide sebagaimana dianjurkan oleh komunikator, berupa penggunaan barang atau jasa yang disarankan, serta kenikmatan yang diperoleh dari penggunaan barang atau jasa tersebut.

Desain komunikasi visual, yang salah satunya berbentuk iklan, berarti dapat dipahami sebagai salah satu upaya pemecahan masalah (komunikasi, atau komunikasi visual) untuk menghasilkan suatu desain iklan yang paling baru di antara desain iklan yang terbaru (Tinarbuko, 2009: 66). Dalam konteks ini, penekanannya dititikberatkan pada upaya pemecahan masalah komunikasi atau komunikasi visual dengan mengedepankan aspek kebaruan sebagai "panglima perangnya". Desain iklan, sebagai suatu sistem pemenuhan kebutuhan manusia di bidang informasi verbal dan visual melalui simbol-simbol kasatmata, dewasa ini mengalami perkembangan sangat pesat. Hampir di segala sektor kegiatan manusia, simbol-simbol visual hadir dalam bentuk gambar, sistem tanda sampai display di berbagai pusat perbelanjaan dengan segala aneka daya tariknya.

Selain itu, profesi desainer iklan menjadi bagian dari mata rantai sebuah penelitian sosial. Desainer iklan, sebelum berkarya haruslah melakukan berbagai kajian dengan pendekatan lintas ilmu. Pengembaraan kreatifnya diawali dari menemukan dan mengenali permasalahan komunikasi visual. Selanjutnya, mencari data verbal dan data visual. Lalu menyusun konsep kreatif berlandaskan karakteristik target sasaran. Terakhir, menentukan visualisasi final desain untuk mendukung tercapainya sebuah komunikasi verbal-visual yang fungsional, persuasif, artistik, estetis, dan komunikatif. Hal itu dilakukan untuk lebih memfokuskan lubang bidik karya desain iklan.

Jenis iklan yang dipaparkan di atas adalah jenis iklan komersial. Pada dasarnya, periklanan dibagi menjadi dua, (1) iklan komersial dan (2) iklan nonkomersial atau biasa disebut Iklan Layanan Masyarakat (ILM), yang akan menjadi inti penelitian ini.

Sementara itu, iklan layanan masyarakat dapat dipahami sebagai sebuah pengumuman atau pemberitahuan yang tidak dipungut bayaran untuk memajukan sebuah program, aktivitas atau layanan pemerintah pusat maupun pemerintah daerah, atau aktivitas sosial untuk layanan organisasi nonprofit dan pemberitahuan 
lain yang dianggap bermanfaat untuk masyarakat (Crompton dan Lamb, 1986: 428).

Berikut ini tabel penjelas yang membedakan antara iklan komersial dengan iklan layanan masyarakat:
Kehadiran ILM dimaksudkan sebagai citra tandingan terhadap keberadaan iklan komersial. Sebagai sebuah citra tandingan, pada dasarnya ILM adalah alat untuk menyampaikan pesan sosial kepada masyarakat. Media semacam ini sering

Iklan Komersial

Iklan Sosial

(Iklan Layanan Masyarakat)

Pesan yang disampaikan berbentuk pesan komersial yang berujung pada keuntungan finansial

Menyampaikan pesan penjualan yang paling persuasif yang diarahkan kepada para calon pembeli yang paling potensial atas produk barang atau jasa tertentu dengan biaya semurahmurahnya (Jefkins, 1996: 5).

Pesan komersial yang menawarkan suatu produk yang ditujukan kepada masyarakat lewat suatu media iklan (Kasali, 1992: 9)

Pesan yang dibayar dan disampaikan melalui sarana media yang bertujuan membujuk konsumen untuk melakukan tindak membeli atau mengubah perilakunya (Nuradi, 1996: 4)

Iklan komersial menjadi sebentuk strategi sosial persuasif yang dimaksudkan untuk memengaruhi cara orang memandang pembelian dan konsumsi barang.

Iklan komersial bertujuan mengangkat dan memancangkan nilai-nilai kenikmataan dalam hidup (Danesi, 2010: 363)

Ada dua ketegori iklan komersial: pertama, periklanan untuk konsumen, yang bertujuan untuk mempromosikan sebuah produk, kedua, periklanan untuk perdagangan, di mana pelemparan barang ke pasar diajukan pada dealer dan kalangan profesional melalui publikasi dan
Pesan yang disampaikan berbentuk pesan sosial

Iklan layanan masyarakat mempunyai peran penting bagi berbagai kegiatan nonbisnis.

Iklan layanan masyarakat dirasakan manfaatnya dalam menggerakkan solidaritas masyarakat manakala menghadapi suatu masalah sosial.

Dalam iklan layanan masyarakat disajikan pesan sosial yang dimaksudkan untuk membangkitkan kepedulian masyarakat terhadap sejumlah masalah yang harus mereka hadapi (Kasali, 1992: 201 ).

Menurut Ad Council, kriteria yang digunakan untuk menentukan kampanye iklan layanan masyarakat adalah: nonkomersial, tidak bersifat keagamaan, nonpolitik, berwawasan nasional, diperuntukkan bagi seluruh lapisan masyarakat, diajukan oleh organisasi yang telah diakui, dapat diiklankan, mempunyai dampak dan kepentingan tinggi sehingga patut memperoleh dukungan media lokal ataupun nasional (Kasali, 1992: 202).

Yang tidak termasuk iklan layanan masyarakat adalah informasi waktu via telepon, prakiraan cuaca, dan pengumuman promosi.

Pemasangan iklan layanan masyarakat tidak dikenakan sewa media (gratis) oleh media massa cetak dan elektronik. 
dimanfaatkan oleh pemerintah untuk menyebarluaskan programnya. Sebagai media yang bergerak dalam bidang sosial, ILM pada umumnya berisi pesan tentang kesadaran nasional, kemanusiaan, kesehatan, pendidikan dan lingkungan hidup. Misalnya ILM yang dibuat untuk menyukseskan program imunisasi nasional, pemberantasan nyamuk demam berdarah, virus flu burung, budaya gemar membaca, budaya menabung, menjaga lingkungan hidup, membuang sampah pada tempatnya, tertib lalulintas, wajib pajak, hemat listrik, donor darah, dan sebagainya.

ILM adalah iklan sosial. Keberadaannya bersifat independen. Ia tidak terkait pada konsep bisnis perdagangan, politik, atau agama. Konsep visualnya tidak berbeda dengan iklan komersial. Keduanya merupakan media komunikasi visual yang berperan untuk mempengaruhi khalayak luas sebagai target sasaran agar dapat tergerak hatinya untuk melakukan sesuatu yang dianjurkan oleh pesan ILM tersebut. Oleh karena itu, perencanaan sebuah ILM mengacu pada konsep iklan komersial.

Jika dilihat dari wujudnya, ILM mengandung tanda dan pesan komunikasi yang komunikatif. Lewat bentuk-bentuk komunikasi seperti itulah pesan verbal dan pesan visual tersebut menjadi bermakna. Di samping itu, gabungan antara tanda dan pesan yang ada pada ILM bertugas mempersuasi khalayak sasaran yang dituju.

Tulisan ini bertujuan untuk mengkaji tanda verbal (terkait dengan judul, subjudul, dan teks) dan tanda visual (terkait dengan ilustrasi, logo, tipografi, dan tata visual) ILM dengan pendekatan teori semiotika, teori periklanan, dan desain komunikasi visual. Dengan demikian, analisis semiotika komunikasi visual dengan dukungan teori semiotika, teori periklanan, dan desain komunikasi visual diharapkan menjadi salah satu pendekatan untuk memperoleh makna konotasi yang terkandung di balik tanda verbal dan tanda visual dalam iklan layanan masyarakat.

Melalui pendekatan teori semiotika, teori periklanan dan teori desain komunikasi visual, diharapkan ILM mampu diklasifikasikan berdasarkan tanda, kode, dan makna yang terkandung di dalamnya. Dengan pendekatan dan teori-teori ini, diharapkan dapat diketahui dasar keselarasan antara tanda verbal dan tanda visual untuk mendukung kesatuan penampilan ILM serta mengetahui hubungan antara jumlah muatan isi pesan (verbal dan visual) dan tingkat kreativitas pembuatan desain ILM.

Pesan yang dikemukakan dalam pesan ILM, disosialisasikan kepada khalayak sasaran melalui tanda. Secara garis besar, tanda dapat dilihat dari dua aspek, yaitu tanda verbal dan tanda visual.

Tanda verbal akan didekati dari gaya bahasanya, tema, dan pengertian yang didapatkan. Sedangkan tanda visual akan dilihat dari cara menggambarkannya, apakah secara ikonis, indeksikal, atau simbolis, dan bagaimana cara mengungkapkan idiom estetik dan kode-kode sosialnya. Tanda-tanda yang telah dilihat dan dibaca

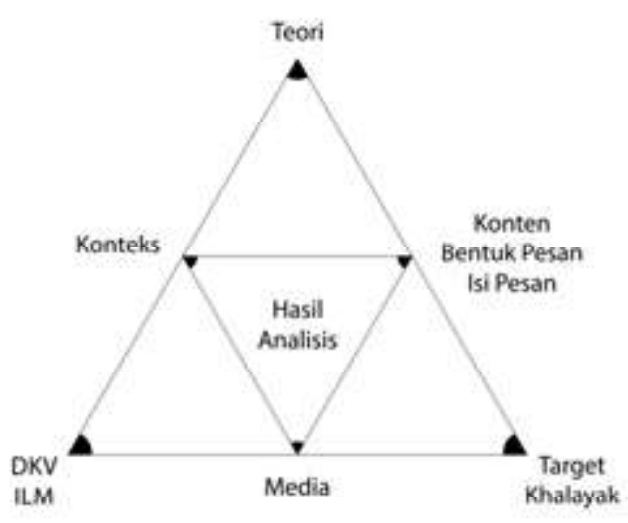

Triadik Sumbo Tinarbuko 


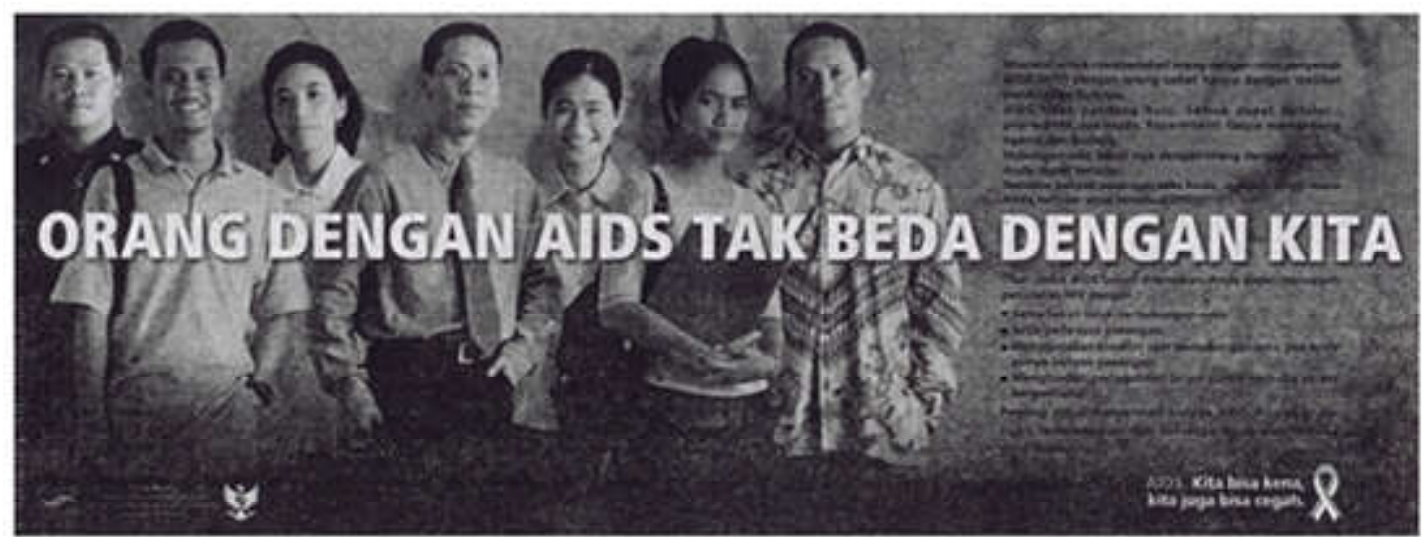

(ILM berukuran 9 kolom kali 15 cm ini dimuat di harian Kompas Minggu, 6 Agustus 2000)

dari dua aspek secara terpisah, kemudian diklasifikasikan, dan dicari hubungan antara yang satu dan yang lainnya.

\section{Semiotika Sebagai Metode Analisis Tanda Verbal dan Tanda Visual ILM}

Metode analisis semiotika komunikasi visual, pada dasarnya beroperasi pada dua jenjang analisis. Pertama, analisis tanda secara individual, mencakup: tanda, kode, dan makna tanda. Kedua, analisis tanda yang membentuk teks. Sedangkan teks menurut Yasraf Amir Piliang (2004: 88) dipahami sebagai kombinasi tanda-tanda. Dengan demikian, karya desain komunikasi visual salah satunya berbentuk ILM juga dapat dilihat sebagai sebuah teks.

Tulisan ini menggunakan metode penelitian kualitatif dengan cara mendeskripsikan, menginterpretasikan, dan menerangkan makna ILM kemudian diklasifikasikan dan dideskripsikan berdasarkan pada teori desain komunikasi visual, dan teori semiotika. Cara melakukan proses analisis objek penelitian dilakukan secara deskriptif dengan memanfaatkan konsep Triadik Sumbo Tinarbuko.

Konsep Triadik Sumbo Tinarbuko penulis ciptakan untuk melihat dan mengidentifikasikan tanda verbal dan tanda visual yang terkandung di dalam ILM sehingga dapat ditemukan makna konotasi atas pesan verbal dan pesan visual yang komunikatif, dan persuasif yang ditujukan pada khalayak sasaran yang dituju.

\section{PEMBAHASAN}

Identifikasi dan Deskripsi Tanda Verbal dan Tanda Visual ILM Tema AIDS (HIV)

Tanda Verbal:

\section{Headline:}

ORANG DENGAN AIDS TAK BEDA DENGAN KITA

\section{Bodycopy:}

Mustahil untuk membedakan orang dengan virus penyebab AIDS (Acquired Immunodeficiency Syndrome) dengan orang sehat hanya dengan melihat penampilan fisiknya. AIDS tidak pandang bulu. Semua dapat tertular: laki-laki-perempuan, tua-muda, kayamiskin. Tanpa memandang agama dan budaya. Hubungan seks sekali saja dengan orang dengan virus ini, Anda dapat tertular. Semakin banyak pasangan seks Anda, semakin tinggi risiko Anda tertular virus tersebut. Obat untuk AIDS belum ditemukan.

Anda dapat mencegah penularan HIV (Human Immunodeficiency Syndrome) 
dengan: Sama sekali tidak berhubungan seks. Setia pada satu pasangan. Menggunakan kondom saat berhubungan seks, jika Anda punya banyak pasangan. Menghindari penggunaan jarum suntik narkoba secara bergantian.

Penting untuk mencermati bahaya AIDS. Bicarakan dengan teman-teman dan Keluarga Anda dan mereka yang Anda cintai.

Slogan:

AIDS. Kita bisa kena, kita juga bisa cegah.

Sponsor:

Kementerian Negara Kesejahteraan Rakyat Republik Indonesia dan AusAID

\section{Tanda Visual:}

Ikon tujuh manusia yang terdiri dari ikon empat laki-laki dan ikon tiga perempuan. Ketujuh ikon manusia sebagai model iklan layanan masyarakat dengan tema AIDS ini ditampilkan mewakili berbagai etnis kesukuan, status sosial, dan profesi di kalangan masyarakat.

Layout atau tatavisual dari ILM ini secara keseluruhan berbentuk empat persegi panjang, dibagi menjadi dua bagian yang asimetris. Bagian kiri terdiri dari dua per tiga bagian diberikan untuk menempatkan ilustrasi yang terdiri dari ikon tujuh manusia yang diposisikan menjadi model dari ILM ini. Sedangkan sepertiga bagian di sebelah kanan, digunakan untuk menempatkan bodycopy atau teks yang menjelaskan bahwa sulit untuk membedakan orang dengan virus penyebab AIDS (HIV) dengan orang sehat hanya dengan melihat penampilan fisiknya. Sementara itu dua bagian asimetris dari penampilan tanda visual ILM ini dihubungkan dengan headline berbunyi: "ORANG DENGAN AIDS TAK BEDA DENGAN KITA" yang membentang dari kiri ke kanan untuk mengaitkan di antara keduanya. Bagian bawah sebelah kanan dari ILM ini ditutup dengan logo AIDS berbentuk pita yang disusun sedemikian rupa membentuk lingkaran kecil di bagian atas, dan di bagian bawah antara satu dan lainnya saling menyilang. Sedangkan bagian bawah sebelah kiri dari ILM ini ditutup dengan lambang negara Indonesia: Garuda Pancasila.

Warna:

ILM 'Pencegahan Bahaya AIDS' ini dibuat dengan latar belakang warna merah dengan tekstur noktah hitam. Bagian bawah dari ILM ini dibaluri warna hitam sebagai warna pengunci dari seluruh warna yang dimunculkan dalam ILM ini.

\section{Komposisi:}

ILM 'Pencegahan Bahaya AIDS' disusun dengan komposisi horizontal dengan menempatkan sepertiga bagian dari bidang ILM tersebut untuk diisi dengan bodycopy. Sedangkan duapertiga dari bidang ILM tersebut diisi dengan menampilkan ilustrasi fotografis model ILM yang terdiri dari tiga perempuan dan empat laki-laki. Kedua bidang teks (bodycopy) dan ilustrasi dihubungkan dengan headline yang berbunyi: ORANG DENGAN AIDS TAK BEDA DENGAN KITA. Bagian bawah dari komposisi bidang ILM tersebut dikunci dengan warna hitam yang menyebar ke 
kiri dan kanan sebagai warna pengunci. Di sisi kanan bidang hitam tersebut diletakkan logo AIDS berbentuk lipatan pita berwarna merah putih yang dibentuk menyerupai huruf A. Sedangkan di sisi sebelah kiri dari bidang ILM tersebut diletakkan logo sponsor yang terdiri dari ikon Burung Garuda sebagai logo Kementerian Negara Kesejahteraan Rakyat Republik Indonesia dan logo AusAID.

\section{Ilustrasi:}

ILM "Pencegahan Bahaya AIDS" menggunakan teknik fotografi untuk menampilkan ilustrasinya. ILM ini menghadirkan empat laki-laki dengan profesi, ekspresi, status sosial dan gaya berbusana yang berbeda antara yang satu dan lainnya. Demikian pula tiga perempuan yang diposisikan bersandingan dengan model laki-laki juga ditampilkan dengan balutan busana, ekspresi, pekerjaan dan status sosial yang berlainan antara perempuan yang satu dan lainnya. Beragam karakter yang dimunculkan oleh model iklan ini dimaksudkan sebagai visualisasi dari headline yang berbunyi: 'ORANG DENGAN AIDS TAK BEDA DENGAN KITA' serta teks yang berbunyi: "Mustahil untuk membedakan orang dengan virus penyebab AIDS dengan orang sehat hanya dengan melihat penampilan fisiknya. AIDS tidak pandang bulu. Semua dapat tertular: laki-laki-perempuan, tua-muda, kayamiskin. Tanpa memandang agama dan budaya. Hubungan seks sekali saja dengan orang dengan virus ini, Anda dapat tertular. Semakin banyak pasangan seks Anda, semakin tinggi risiko Anda tertular virus tersebut. Obat untuk AIDS belum ditemukan."
Tipografi:

ILM 'Pencegahan Bahaya AIDS' menggunakan tipografi yang berasal dari keluarga huruf sans serif. Sebuah keluarga huruf yang menampilkan struktur tubuh tipografi tanpa menggunakan kaki. Nama keluarga huruf sans serif ini: Calibri.

Ukuran:

ILM 'Pencegahan Bahaya AIDS' berukuran 9 kolom $X 15 \mathrm{~cm}$, diletakkan secara horizontal di bagian bawah halaman 13 harian Kompas yang terbit tanggal 6 Agustus 2000.

\section{Analisis Penggunaan Gaya Bahasa dalam ILM Tema AIDS (HIV)}

Iklan Layanan Masyarakat (ILM) dengan tema AIDS (HIV) ini berdasarkan pilihan kata menggunakan gaya bahasa tidak resmi, hal itu terlihat pada headline, bodycopy, dan slogan yang disusun dengan pilihan kata-kata yang lebih singkat dan sederhana.

Gaya bahasa berdasarkan nada pada bodycopy ILM cenderung menggunakan gaya bahasa sederhana, karena di dalamnya memberi instruksi dan pelajaran akan pentingnya menghindarkan diri dari penyakit AIDS (HIV). Hal itu terlihat pada kalimat yang diposisikan sebagai bodycopy dari iklan layanan masyarakat tersebut.

Gaya bahasa antitesis juga digunakan dalam ILM ini. Gaya bahasa antitesis yang mengandung gagasan-gagasan yang bertentangan, dengan menggunakan katakata atau kelompok kata yang berlawan. Hal itu terlihat pada bodycopy yang berbunyi: "... Semua dapat tertular: laki-lakiperempuan, tua-muda, kaya miskin."

Gaya bahasa repetisi juga digunakan dalam ILM ini. Repetisi yang dimaksudkan sebagai perulangan bunyi, suku kata, kata 
atau bagian kalimat yang dianggap penting untuk memberi tekanan dalam sebuah konteks yang sesuai. Hal itu terlihat pada kata "seks" yang tercantum dalam bodycopy dari iklan layanan masyarakat tersebut. Gaya bahasa repetisi juga terlihat pada kata "kita" yang tercantum dalam slogan ILM ini: "AIDS. Kita bisa kena, kita juga bisa cegah."

Analisis Semiotika Komunikasi Visual pada ILM 'Pencegahan Bahaya AIDS'

Secara konotatif, pesan verbal yang muncul dari tanda verbal ILM 'Pencegahan Bahaya AIDS' ini adalah: semakin banyak berganti-ganti pasangan dalam melakukan hubungan seks, maka mereka semakin tinggi risikonya tertular virus tersebut.

Sedangkan pesan visual dalam ILM 'Pencegahan Bahaya AIDS' ini dapat dideskripsikan dengan melihat visualisasi tanda-tanda visual yang ada. Tanda visual dalam ILM 'Pencegahan Bahaya AIDS' ini menghadirkan tujuh ikon manusia berjenis kelamin perempuan dan laki-laki.

Jika dilihat dari sebelah kiri, model ILM yang pertama, terlihat ikon laki-laki berprofesi sebagai pengawal pribadi dalam posisi siap siaga mengawal dan memberikan perlindungan pada orang yang membayar jasa keamanan pada dirinya. Secara indeksikal menegaskan indeks atas penanda profesi pengawal pribadi yang dibayar oleh pejabat, artis, atau tokoh masyarakat atas jasa pengawalan dan jasa keamanan dari orang yang membayarnya.

Model ILM kedua terlihat ikon laki-laki yang sedang tersenyum ramah. Ikon lakilaki tersebut mengenakan kaos berkerah warna abu-abu dengan pelisir garis hitam yang ditorehkan melingkar pada krah kaosnya. Secara indeksikal ikon laki-laki model kedua ILM ini memiliki penanda sebagai seorang mahasiswa.
Model ILM ketiga tervisualkan berupa ikon perempuan berambut pendek dengan memakai baju krem bermotifkan polkadot. Ikon perempuan ini secara indeksikal terlihat sebagai wanita karir yang bekerja pada sebuah instansi negeri atau kantor perusahaan swasta.

Model ILM keempat tervisualkan berupa ikon seorang laki-laki eksekutif muda yang bekerja di sebuah kantor. Indeksikal ikon laki-laki eksekutif muda ini terlihat dari penanda yang dimunculkan lewat busana pantalon: celana panjang warna hitam, ikat pinggang warna hitam, kemeja eksekutif lengan panjang berwarna abu-abu.

Model ILM kelima, secara visual terlihat ikon perempuan yang tersenyum ramah. Penanda potongan rambut yang dibelah pinggir dan dikucir ke belakang menjadi indeks sekaligus simbol yang menyebutkan dirinya adalah wanita karir sekaligus ibu rumah tangga yang hangat dan sayang pada keluarganya.

Model ILM keenam adalah ikon perempuan muda yang sedang tersenyum manis menghadap target sasaran dari ILM ini. Berdasarkan penanda yang dimuncul-kan oleh ikon perempuan model ILM ini, maka penanda tersebut memiliki tanda indeksikal sekaligus simbol yang meng-arahkan ikon perempuan itu sebagai sosok mahasiswi tingkat akhir dari sebuah universitas.

Model ILM ketujuh berwujud ikon laki-laki setengah baya. Melihat tampilan visual ikon laki-laki model ketujuh ILM ini, secara indeksikal, ikon laki-laki tersebut menghadirkan penanda seorang pejabat publik yang selalu mengedepankan sikap formal. Simbolisasi pose dan ekspresi wajah seperti itulah yang biasa dilakukan oleh pejabat publik.

Makna konotasi yang muncul dari ketujuh tanda visual yang dimunculkan 
dalam ILM ini bahwa siapa pun, entah itu laki-laki atau perempuan, memiliki status sosial atau pun tidak, bekerja atau tidak, kaya atau pun miskin ketika melakukan seks bebas dengan berganti-ganti pasangan, besar kemungkinan tertular penyakit AIDS. Makna konotasi lainnya muncul secara egaliter dari tanda visual dapat ditunjukkan lewat headline dari ILM ini yang berbunyi: 'ORANG DENGAN AIDS TAK BEDA DENGAN KITA'

Itulah makna konotasi yang muncul dari pesan visual berdasarkan tanda visual yang divisualisasikan berwujud tujuh orang dengan empat laki-laki dan tiga perempuan yang menjadi model ILM ini. Pesan visual ILM tersebut secara konotatif ingin mengatakan kepada target sasaran bahwa keberagaman ekspresi, keberagaman profesi, keberagaman jenis kelamin, keberagaman tingkat pendidikan, dan keberagaman etnis kesukuan menjadikan penderita AIDS tidak berbeda dengan masyarakat lainnya.

Sebaliknya, meski dengan keberagaman ekspresi, keberagaman profesi, keberagaman jenis kelamin, keberagaman tingkat pendidikan, dan keberagaman etnis kesukuan, tetapi kalau mereka melakukan aktivitas hubungan kelamin dengan berganti-ganti pasangan secara bebas, maka mereka akan semakin tinggi memiliki risiko tertular penyakit AIDS. Untuk itu, seperti yang dikatakan dalam slogan komunitas AIDS, kita bisa kena, tetapi kita juga memiliki kewajiban untuk mencegahnya. Oleh karena itu, ILM ‘Pencegahan Bahaya AIDS' ini dibuat untuk mengupayakan pencegahan atau minimalnya mengurangi jumlah orang yang terjangkiti penyakit AIDS.

Berdasarkan tanda verbal dan tanda visual tersebut di atas, maka pesan verbal dan pesan visual yang terkandung dalam ILM
'Pencegahan Bahaya AIDS' makna konotasinya dapat dibongkar lebih mendalam dengan menggunakan kode sosial seperti yang dilakukan Roland Barthes dalam bukunya S/Z. Hal itu perlu dilakukan agar makna konotasi yang ada dalam pesan verbal dan pesan visual ILM tersebut dapat mengemuka secara konotatif dan komunikatif.

Mengapa demikian? Sebab makna konotasi menurut Barthes seperti dikutip Fiske (2005: 119) berupaya menggambarkan interaksi yang berlangsung manakala tanda verbal dan tanda visual bertemu dengan perasaan atau emosi penggunanya dan nilai-nilai kulturalnya. Sementara Roland Barthes dalam bukunya berjudul: Image-Music-Text (2010: 3) menyebutkan makna konotatif adalah pandangan atau pendirian masyarakat tentang apa yang disodorkan kepadanya. Untuk itu pesan verbal dan pesan visual yang mengandung makna konotatif harus diuraikan.

Berdasarkan tanda verbal dan tanda visual yang ada dalam ILM 'Pencegahan Bahaya AIDS' maka untuk mempertajam makna konotasi yang terkandung dalam pesan verbal dan pesan visual dapatlah dilihat dengan menggunakan bantuan kode narasi dan kode kebudayaan.

Kode kebudayaan dalam ILM 'Pencegahan Bahaya AIDS' ini terlihat pada adanya aspek pengetahuan. Hal itu muncul dari bodycopy yang memberikan informasi sekaligus pengetahuan bahwa penularan penyakit AIDS disebabkan oleh orang yang sering melakukan hubungan seksual dengan berganti-ganti pasangan tanpa menggunakan kondom.

Pengetahuan lainnya yang dapat diuraikan dari kode kebudayaan adalah: bagi siapa pun, agama dan status sosial apapun, entah masih berusia muda atau sudah tua, dari suku bangsa dan etnis mana pun, selama 
mereka suka memburu nafsu syahwat dengan melakukan hubungan seksual secara bebas di lokalisasi pelacuran dengan pekerja seks komersial, kemungkinan besar akan tertular virus HIV yang menyebabkannya menderita penyakit AIDS. Selain akibat melakukan hubungan seks secara bebas dengan banyak pasangan, kode kebudayaan memberikan informasi lain dari sisi pengetahuan perihal penyebab penyebaran penyakit AIDS, yaitu penyakit yang diakibatkan dari sindrom hilangnya kekebalan tubuh.

Pengetahuan lain dari kode kebudayaan yang ada dalam pesan verbal 'Pencegahan Bahaya AIDS' yakni, di mata masyarakat luas, orang yang menderita penyakit AIDS selalu dihindari untuk berinteraksi secara sosial, bahkan terkadang para penderita penyakit AIDS itu dikucilkan dari lingkungan sosialnya. Karena itulah ILM versi 'Pencegahan Bahaya AIDS' memasang headline yang secara visual diletakkan tepat di jantung para model ILM tersebut dengan kalimat yang berbunyi: 'ORANG DENGAN AIDS TAK BEDA DENGAN KITA.'

Headline ini berupaya memberikan informasi lewat kode kebudayaan khususnya pada aspek pengetahuan yang menyatakan: 'ORANG DENGAN AIDS' yang memiliki makna konotasi penderita AIDS atau orang yang terjangkiti virus HIV akibat perilakunya yang menyimpang atau penyebab lainnya. Dapat juga diberi makna konotasi, anak yang dilahirkan dari orang tua yang menderita AIDS yang menyebabkan si anak tersebut menanggung dosa asal dengan terpaksa menjadi penderita AIDS karena ulah orang tuanya.

Penggalan lain dari headline itu berbunyi: 'TAK BEDA DENGAN KITA.' Headline tersebut jika ditilik dari aspek pengetahuan yang terdapat di dalam kode kebudayaan memiliki makna konotasi bahwa penderita AIDS tidak boleh dikucilkan dari lingkungan sosial kemasyarakatan. Mengapa demikian, sebab secara kasatmata mereka tidak berbeda sama sekali dengan masyarakat lain. Bahkan antara yang satu dan lainnya terlihat sama.

Aspek mitos dan suara-suara yang bersifat kolektif yang ada pada kode kebudayaan dapat pula digunakan untuk memberikan makna konotasi. Aspek mitos dan suara-suara yang bersifat kolektif itu terlihat pada teks 'Obat untuk AIDS belum ditemukan'. Akibat mitos tersebut, masyarakat mendengarkan suara-suara yang bersifat kolektif yang menyatakan penderita penyakit AIDS belum bisa disembuhkan karena belum ada obat yang mampu menyembuhkannya. Makna konotatif yang muncul dari teks 'Obat untuk AIDS belum ditemukan' adalah dengan mengucilkan penderita AIDS dari lingkungan sosial kemasyarakatan.

Aspek psikologis dapat digunakan untuk membantu memunculkan makna konotasi dari ILM tersebut. Hal ini dapat dilihat dari perilaku sosial psikologis masyarakat terhadap penderita AIDS. Masyarakat cenderung menghindar jika bertemu dengan orang yang diketahui menderita penyakit AIDS. Masyarakat merasa takut jika berdekatan dengan penderita AIDS akan tertular penyakit tersebut. Padahal realitas sosialnya, penularan penyakit AIDS harus lewat kontak fisik berupa hubungan kelamin atau lewat jarum suntik. Sementara di sudut lain, penderita AIDS secara psikologis merasakan dirinya hancur secara sosial dan moral. Keberadaannya di mata masyarakat seakanakan menjadi sampah masyarakat akibat penyakit yang dideritanya.

Aspek kebijaksanaan dapat juga digunakan untuk membantu memunculkan makna konotasi dari iklan tersebut. Hal itu 
dapat dilihat dari headline yang berbunyi "ORANG DENGAN AIDS TIDAK BEDA DENGAN KITA" Headline ini memunculkan makna konotasi yang menyatakan bahwa kita harus berlaku bijaksana manakala menghadapi realitas sosial yang menunjukkan keberadaan penderita AIDS di lingkungan sekitar. Sikap bijaksana itu harus selalu didengungkan kepada siapa pun bahwa kenyataannya, sebagai manusia, kita tidak boleh membeda-bedakan siapa pun, apakah karena berbeda suku, agama, apalagi kondisi sosial ekonomi dan kesehatan. Justru sebaliknya, kita harus membantu sesama manusia yang kebetulan menyandang penyakit AIDS.

Aspek kebijaksanaan lainnya dapat terlihat dari paparan penggalan teks iklan yang berbunyi: "... Hubungan seks sekali saja dengan orang dengan virus ini, Anda dapat tertular. Semakin banyak pasangan seks Anda, semakin tinggi risiko Anda tertular virus tersebut ..." Dari teks tersebut di atas lewat bantuan aspek kebijaksanaan dalam kode kebudayaan dapat dimunculkan makna konotasi sebagai berikut: makna konotasi yang muncul, manusia sebagai makhluk sempurna yang diciptakan Tuhan harus selalu berlaku bijaksana dalam menjalankan hidup dan kehidupannya. Artinya, sebagai makhluk hidup yang memiliki sifat individu dan sosial, harus selalu mengedepankan sikap bijaksana dalam berlaku dan bertindak. Dalam konteks ini, bagi laki-laki dan perempuan yang tergabung dalam ikatan lembaga perkawinan, bijaksana dalam berlaku dan bertindak itu salah satunya lewat perilaku seks sehat dengan senantiasa setia pada pasangannya. Hal semacam itu menjadi penting untuk dijadikan sikap hidup bagi pasangan suami istri, sebab jika tidak, penggalan teks dalam ILM ini yang berbunyi: "... Hubungan seks sekali saja dengan orang dengan virus ini, Anda dapat tertular. Semakin banyak pasangan seks Anda, semakin tinggi risiko Anda tertular virus tersebut ...", akan menjadi kenyataan.

Kode narasi dapat juga membantu memunculkan makna konotasi. Sebab kode narasi pada dasarnya adalah kode yang mengandung cerita, urutan, dan narasi atau antinarasi. Kode narasi dalam ILM ini terlihat dari deskripsi ILM yang menceritakan upaya pencegahan penyakit AIDS lewat headline berbunyi "ORANG DENGAN AIDS TAK BEDA DENGAN KITA"

Sedangkan alur narasinya sebagai berikut: ILM 'Pencegahan Bahaya AIDS' menggunakan teknik fotografi untuk menampilkan ilustrasinya. ILM ini menghadirkan empat laki-laki dengan profesi, ekspresi, status sosial dan gaya berbusana yang berbeda antara yang satu dan lainnya. Demikian pula tiga perempuan yang diposisikan bersandingan dengan model laki-laki juga ditampilkan dengan balutan busana, ekspresi, pekerjaan dan status sosial yang berlainan antara perempuan yang satu dan lainnya. Beragam karakter yang dimunculkan oleh model iklan ini dimaksudkan sebagai visualisasi dari headline yang berbunyi: 'ORANG DENGAN AIDS TAK BEDA DENGAN KITA' serta teks yang berbunyi: "Mustahil untuk membedakan orang dengan virus penyebab AIDS dengan orang sehat hanya dengan melihat penampilan fisiknya. AIDS tidak pandang bulu. Semua dapat tertular: lakilaki-perempuan, tua-muda, kaya-miskin, tanpa memandang agama dan budaya. Hubungan seks sekali saja dengan orang dengan virus ini, Anda dapat tertular. Semakin banyak pasangan seks Anda, semakin tinggi risiko Anda tertular virus tersebut. Obat untuk AIDS belum ditemukan." 
Dari analisis semiotika komunikasi visual berdasarkan tanda verbal dan tanda visual yang dipaparkan di atas, dapat dikatakan, rajutan tali hubungan yang erat antara tanda verbal dan tanda visual itu terlihat pula pada penempatan headline ILM tersebut yang berbunyi 'ORANG DENGAN AIDS TAK BEDA DENGAN KITA' Headline tersebut ditempatkan melintang horizontal, keberadaannya mengikat sekaligus menyambungkan pesan verbal dan pesan visual kepada target sasaran bahwa siapa pun dapat terjangkiti AIDS, sebaliknya dengan kesadaran penuh, kita dapat mencegah penyebaran virus AIDS. Sementara itu, tanda verbal dan tanda visual yang terkandung di dalam ILM 'Pencegahan Bahaya AIDS' terdapat hubungan yang erat antara tanda verbal yang direpresentasikan melalui headline, body copy, tagline dan tanda visual yang direpresentasikan melalui ikon dan indeks dari ketujuh laki-laki dan perempuan yang menjadi model dari ILM tersebut.

Berdasarkan hal tersebut di atas, maka kesimpulannya, tanda verbal dan tanda visual yang muncul dalam ILM 'Pencegahan Bahaya AIDS' memiliki makna konotasi tebaran pengetahuan untuk memahami, menghindari, dan menyegah terjangkitnya virus AIDS.

\section{SIMPULAN}

Pertama, tulisan ini mengkaji tanda verbal (terkait dengan judul, subjudul, dan teks) dan tanda visual (terkait dengan ilustrasi, logo, tipografi, dan tatavisual) ILM serta mencari makna konotasi atas keberadaan pesan verbal dan pesan visual. Secara visual ILM mengandung tanda verbal dan tanda visual yang direpresentasikan secara komunikatif. Lewat karya desain komunikasi visual berbentuk iklan layanan masyarakat seperti itulah pesan verbal dan pesan visual tersebut menjadi bermakna. Di samping itu, gabungan antara tanda dan pesan yang ada pada iklan layanan masyarakat mampu memberikan persuasi pada khalayak sasaran yang dituju. Sementara itu, pesan verbal dan pesan visual yang dikemukakan dalam pesan ILM, disosialisasikan kepada khalayak sasaran melalui tanda. Secara garis besar, tanda dapat dilihat dari dua aspek, yaitu tanda verbal dan tanda visual.

Kedua, analisis semiotika komunikasi visual untuk objek iklan layanan masyarakat dengan dukungan teori semiotika, teori gaya bahasa, dan teori desain komunikasi visual diharapkan menjadi salah satu pendekatan baru untuk memperoleh makna konotasi yang terkandung di balik tanda verbal dan tanda visual dalam iklan layanan masyarakat tersebut. Sebab dengan mengkaji tanda verbal (terkait dengan judul, subjudul, dan teks) dan tanda visual (terkait dengan ilustrasi, logo, tipografi, gaya desain, dan komposisi) ILM dengan pendekatan teori semiotika, teori gaya bahasa, dan teori desain komunikasi visual, akan memunculkan makna konotasi yang plural dan polisemi.

Ketiga, semua unsur semiotika yang meliputi tanda, kode, dan makna menjadi pertimbangan dalam melihat dan menangkap pesan yang mencuat dalam karya desain komunikasi visual. Hubungan ketiga unsur tersebut sangat erat. Antara yang satu dan lainnya saling melengkapi. Dengan demikian, karya desain komunikasi visual berwujud iklan layanan masyarakat yang dijadikan objek kajian setelah ditafsirkan berlandaskan tanda verbal dan tanda visual, dapat diklasifikasikan berdasarkan kombinasi antara tanda, kode, dan makna. Terkait dengan hubungan ketiga komponen tersebut, muncul entropi (tidak terjadi pengulangan) terhadap 
hubungan objek karya desain komunikasi visual, konteks, dan teks, sehingga hasil penafsiran makna menjadi relatif ideal, karena informasi yang disampaikan sangat efektif dan persuasif. Masing-masing komponen menempati posisinya sesuai dengan porsinya masing-masing.

Keempat, untuk membaca, mengidentifikasikan dan memunculkan makna konotasi pada karya desain komunikasi visual berwujud desain iklan layanan masyarakat dibutuhkan metode analisis semiotika komunikasi visual yang juga dimanfaatkan sebagai metode analisis data verbal dan data visual. Selain itu, penggunaan metode analisis semiotika komunikasi visual sebagai salah satu metode pembacaan ILM disebabkan adanya kecenderungan untuk memandang berbagai hal seperti seni, budaya, sosial, desain komunikasi visual, dan ILM sebagai fenomena bahasa dan tanda. Metode analisis semiotika komunikasi visual, pada dasarnya beroperasi pada dua jenjang analisis, yaitu, analisis tanda secara individual yang mencakup: tanda, kode, dan makna tanda, serta analisis tanda yang membentuk teks. Sedangkan teks menurut Yasraf Amir Piliang (2004: 88) dipahami sebagai kombinasi tanda-tanda. Dengan demikian, karya desain komunikasi visual yang salah satunya berbentuk ILM juga dapat dilihat sebagai sebuah teks.

Kelima, cara melakukan proses analisis objek penelitian dilakukan secara deskriptif dengan memanfaatkan konsep Triadik Sumbo Tinarbuko. Konsep ini penulis ciptakan untuk melihat dan mengidentifikasikan tanda verbal dan tanda visual yang terkandung di dalam ILM sehingga mampu ditemukan makna konotasi atas pesan verbal dan pesan visual yang komunikatif, dan persuasif yang ditujukan pada khalayak sasaran yang dituju.

\section{Daftar Pustaka}

Alo Liliweri

1991 Memahami Peran Komunikasi Massa dalam Masyarakat. Bandung: Penerbit PT Citra Aditya Bakti.

Barthes, Roland

1974 "S/Z" terjemahan dari S/Z oleh Richard Miller. New York: Hill and Wang.d

1998 The Semiotics Challenge. New York: Hill and Wang.

Berger, Arthur Asa

2000 "Tanda-tanda dalam Kebudayaan Kontemporer" terjemahan dari Signs in Contemporary Culture: An Introduction to Semiotics oleh M. Dwi Marianto dan Sunarto. Yogyakarta: Penerbit PT Tiara Wacana.

Crompton. J.L. and C.W. Lamb

1986 Marketing Government and Social Service. New York: John Willey and Son.

Danesi, Marcel

2010 "Pesan, Tanda, dan Makna: Buku Teks Dasar Mengenai Semiotika dan Teori Komunikasi" terjemahan dari Messages, Signs, and Meaning: $A B a-$ sic Textbook in Semiotics and Communication Theory oleh Evi Setyarini dan Lusi Lian Piantari. Yogyakarta: Penerbit Jalasutra.

Eco, Umberto

1979 A Theory of Semiotics. Bloomington: Indiana University Press.

Jefkins, Frank

1996 "Periklanan" terjemahan dari Advertising oleh Haris Munandar. Jakarta: Penerbit Erlangga.

Kotler, Philip

1991 "Marketing" terjemahan dari Marketing Esentials oleh Herujati Purwoko. Jakarta: Penerbit Erlangga.

Kasali, Rhenald

1992 Manajemen Periklanan: Konsep dan Aplikasinya Di Indonesia. Jakarta: Penerbit Pustaka Utama Grafiti. 
Luxemburg, Jan van., Bal, Mieke., dan Weststeijn, Willem, G.

1992 "Pengantar Ilmu Sastra" tererjemahan dari Inleiding in de Literatuurwetenschap oleh Dick Hartoko. Jakarta: Penerbit PT Gramedia Pustaka Utama.

Noth, Winfriend

1995 Handbook of Semiotics. Blommington and Indianapolis: Indiana University Press.

Nuradi

1996 Kamus Istilah Periklanan Indonesia. Jakarta: Penerbit PT Gramedia Pustaka Utama.

Saussure, Ferdinand de

1998 "Pengantar Linguistik Umum" terjemahan dari Cours De Linguistique Generale oleh Rahayu S. Hidayat. Yogyakarta: Gadjahmada University Press.

Soepomo Poedjosoedarmo

1986 "Perkembangan Sosiolinguistik". Yogyakarta: Kliping Tulisan dan Artikel di berbagai Seminar Nasional dan Internasional.

Selden, Raman

1991 "Panduan Pembaca Teori Sastra Masa Kini" terjemahan dari $A$ Reader's Guide To Contemporary Literary Theory oleh Rachmat Djoko Pradopo. Yogyakarta: Penerbit Gadjah Mada University Press.
Spradly, James, P.

1997 "Metode Etnografi" terjemahan dari The Etnographic Interview.oleh Misbah Zulfa Elizabeth. Yogyakarta: Penerbit PT Tiara Wacana.

Sumbo Tinarbuko

2009 Semiotika Komunikasi Visual (Edisi Revisi). Yogyakarta: Penerbit Jalasutra.

Williamson, Judith

1984 Decoding Advertisements, Ideology and Meaning in Advertising. London: Marion Boyars Publishers Ltd.

Yasraf Amir Piliang

1998 Sebuah Dunia yang Dilipat, Realitas Kebudayaan menjelang Milenium Ketiga dan Matinya Posmodernisme. Bandung: Penerbit Mizan.

\section{Zoest, Aart van}

1993 "Semiotika Tentang Tanda, Cara Kerjanya dan Apa yang Kita Lakukan Dengan" terjemahan dari Semiotiek, Overteken, hoe ze werken en wat we ermee doen oleh Ani Soekowati. Jakarta: Yayasan Sumber Agung. 